\title{
Yellow nutsedge WRI4-like gene improves drought tolerance in Arabidopsis thaliana by promoting cuticular wax biosynthesis
}

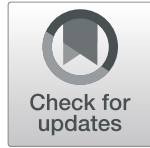

Chao Cheng' ${ }^{1}$ Shutong Hu', Yun Han'1, Di Xia', Bang-Lian Huang', Wenhua Wu', Jamshaid Hussain², Xuekun Zhang ${ }^{3^{*}}$ and Bangquan Huang ${ }^{1 *}$

\begin{abstract}
Background: Cuticular wax plays important role in protecting plants from drought stress. In Arabidopsis WRI4 improves drought tolerance by regulating the biosynthesis of fatty acids and cuticular wax. Cyperus esculentus (yellow nutsedge) is a tough weed found in tropical and temperate zones as well as in cooler regions. In the current study, we report the molecular cloning of a WRI4-like gene from Cyperus esculentus and its functional characterization in Arabidopsis.

Results: Using RACE PCR, full-length WRI-like gene was amplified from yellow nutsedge. Phylogenetic analyses and amino acid comparison suggested it to be a WRI4-like gene. According to the tissue-specific expression data, the highest expression of WRI4-like gene was found in leaves, followed by roots and tuber. Transgenic Arabidopsis plants expressing nutsedge WR/4-like gene manifested improved drought stress tolerance. Transgenic lines showed significantly reduced stomatal conductance, transpiration rate, chlorophyll leaching, water loss and improved water use efficiency (WUE). In the absence of drought stress, expression of key genes for fatty acid biosynthesis was not significantly different between transgenic lines and WT while that of cuticular wax biosynthesis genes was significantly higher in transgenic lines than WT. The PEG-simulated drought stress significantly increased expression of key genes for fatty acid as well as wax biosynthesis in transgenic Arabidopsis lines but not in WT plants. Consistent with the gene expression data, cuticular wax load and deposition was significantly higher in stem and leaves of transgenic lines compared with WT under control as well as drought stress conditions.
\end{abstract}

Conclusions: WR/4-like gene from Cyperus esculentus improves drought tolerance in Arabidopsis probably by promoting cuticular wax biosynthesis and deposition. This in turn lowers chlorophyll leaching, stomatal conductance, transpiration rate, water loss and improves water use efficiency under drought stress conditions. Therefore, CeWRI4-like gene could be a good candidate for improving drought tolerance in crops.

Keywords: Cyperus esculentus, WRI4-like gene, Cuticular wax biosynthesis, Drought tolerance, Gene expression

\footnotetext{
*Correspondence: zhang.xk@139.com; huangbangquan@163.com

${ }^{3}$ Hubei Key Laboratory of Waterlogging Disaster and Agricultural Use of Wetland, Yangtze University, Jingzhou 434023, China

${ }^{1}$ State Key Laboratory of Biocatalysis and Enzyme Engineering, College of Life Science, Hubei University, Wuhan 430062, China

Full list of author information is available at the end of the article
}

(c) The Author(s). 2020 Open Access This article is licensed under a Creative Commons Attribution 4.0 International License, which permits use, sharing, adaptation, distribution and reproduction in any medium or format, as long as you give appropriate credit to the original author(s) and the source, provide a link to the Creative Commons licence, and indicate if changes were made. The images or other third party material in this article are included in the article's Creative Commons licence, unless indicated otherwise in a credit line to the material. If material is not included in the article's Creative Commons licence and your intended use is not permitted by statutory regulation or exceeds the permitted use, you will need to obtain permission directly from the copyright holder. To view a copy of this licence, visit http://creativecommons.org/licenses/by/4.0/. The Creative Commons Public Domain Dedication waiver (http://creativecommons.org/publicdomain/zero/1.0/) applies to the data made available in this article, unless otherwise stated in a credit line to the data. 


\section{Background}

Aerial surfaces of terrestrial plants are covered with a layer of cuticular wax, which protects plants from pathogen infection [1], insect attack [2], UV radiation [3, 4] and drought stress [5-10]. Cuticular wax is a complex mixture consisting mainly of very-long-chain fatty acids (VLCFAs) and their derivatives [11-13]. First C16 and C18 fatty acids are synthesized in plastids and then hydrolyzed and exported to the cytoplasm. The synthesized C16 and C18 coenzyme As (CoAs) are elongated into VLCFAs and then modified into primary alcohols and wax esters by alcohol-forming pathway, or into aldehydes, alkanes, secondary alcohols and ketones by alkane-forming pathway $[14,15]$. The regulation of cuticular wax biosynthesis takes place at transcriptional $[6,14,16-19]$, posttranscriptional [20, 21] and posttranslational levels [22]. Many attempts have been made to increase the cuticular wax content in plant organs with an ultimate objective of improving drought stress tolerance $[6,16,18,23-26]$.

The AP2 (APETALA2)/EREBP (Ethylene Responsive Element Binding Protein) transcription factors contain either a single or two AP2/ERF domains and are involved in various biotic and abiotic stresses response [27]. Arabidopsis WRI1 gene, cloned by Cernac and Benning (2004), was placed in AP2 subfamily since it contained two AP2/EREB domains [28]. The WRI1-like group consists of four members, namely WRI1 (At3g54320), WRI2 (At2g41710), WRI3 (At1g16060) and WRI4 (At1g79700). Previously the WRI1-like group was considered to be part of the ANT-like group [29], while others regarded it as a monophyletic group of the AP2 subfamily [30]. Three members of WRI1-like group, namely WRI1, WRI3 and WRI4, play role in activation of fatty acid biosynthesis [28, 30], while the fourth member WRI4 is involved in drought tolerance in Arabidopsis through regulation of cuticular wax biosynthesis in stem [10].

Cyperus esculentus (yellow nutsedge), a crop of the sedge family, is widespread across much of the globe. It is considered a crop native to areas in Africa and tropical Asia [3133]. It is also found in tropical and subtropical regions of Asia, Europe, Africa and North America [34, 35]. The tubers and seeds of yellow nutsedge can easily be dispersed and get mixed up with crop seeds [36-38]. As its tubers are enriched in sugar, protein, starch, fibers, minerals, vitamins and oil, efforts are underway to develop yellow nutsedge as a new oil crop [39-41]. In the current study we report the cloning and characterization of a WRI4-like gene from Cyperus esculentus (CeWRI4). The gene was introduced in Arabidopsis for its functional characterization.

\section{Results and discussions}

\section{WRI4 nature of the nutsedge gene}

In this study, first a $490 \mathrm{bp}$ fragment corresponding to the conserved region of nutsedge WRI-like gene was amplified through RT-PCR by using degenerated primers (Additional file 1). Subsequently, a $1423 \mathrm{bp}$ full length fragment was obtained by using the 5 ' - and 3 '-RACE PCRs (Additional file 1). The amplified gene contained an ORF of $1098 \mathrm{bp}, 5$ 'UTR (untranslated region) and 3'UTR (Additional file 2). Conserved domain analysis indicated that this WRI-like gene contained two AP2 domains, with the second domain being more conserved than the first one as shown by multiple alignment analysis (data not shown). This sequence is deposited in NCBI Genbank as accession MW039149.

AP2/EREB genes are classified into five groups, namely AP2 subfamily with two AP2/ERF domains, DREB and ERF subfamilies with one AP2/ERF domain, RAV subfamily with one AP2/ERF domain and B3 DNA-binding motif, and others [42-44]. In this study the two AP2 domaincontaining genes clustered into three major groups: AP2, ANT and WRI. In the WRI group the WRI1s were clearly separated from WRI2s, WRI3s and WRI4s, and the nutsedge WRI-like gene was found to be more closely related to WRI3s and WRI4s (Additional file 3). Amino acid sequence comparison indicated that this nutsedge WRI-like peptide showed 31.06 and $52.03 \%$ amino acid sequence similarity with Arabidopsis WRI3 and WRI4, respectively, therefore it was named as C. esculentus WRI4 (CeWRI4). We then determined the expression of CeWRI4 in different organs. CeWRI4 showed the highest expression in leaves, followed by roots and tubers (Additional file 4).

\section{The expression of CeWRI4 improved drought tolerance in transgenic Arabidopsis}

For functional characterization of the cloned gene, Arabidopsis thaliana plants were transformed with CeWRI4 and drought tolerance of transgenic plants was determined by growing on PEG-supplemented growth media as well as by applying real dehydration. Seed germination of both WT and transgenic Arabidopsis was higher than 90\% in both control and PEG-simulated stress conditions (data not shown). We also determined drought tolerance at seedling stage. In control conditions, the growth of 10day-old WT seedlings was not significantly different from transgenic lines B1 and K2 (Fig. 1a). However, under PEGinduced drought stress, WT seedlings exhibited severe inhibition of primary root growth and much fewer lateral roots compared with transgenic lines (Fig. 1a). Under drought stress condition transgenic lines had more number of leaves than WT. Two-week-old transgenic plants had 4 well-developed true leaves compared with two very small and yellow true leaves in same-aged WT plants (Fig. 1a). The root length and seedling fresh weight (FW) data also confirmed that the transgenic lines exhibited higher tolerance to PEG-simulated drought stress (Fig. 1b-c).

We also determined the plant drought tolerance through real dehydration by withholding water. The growth of WT and transgenic Arabidopsis plants was not significantly different under normal growth conditions (Fig. 2). However, 


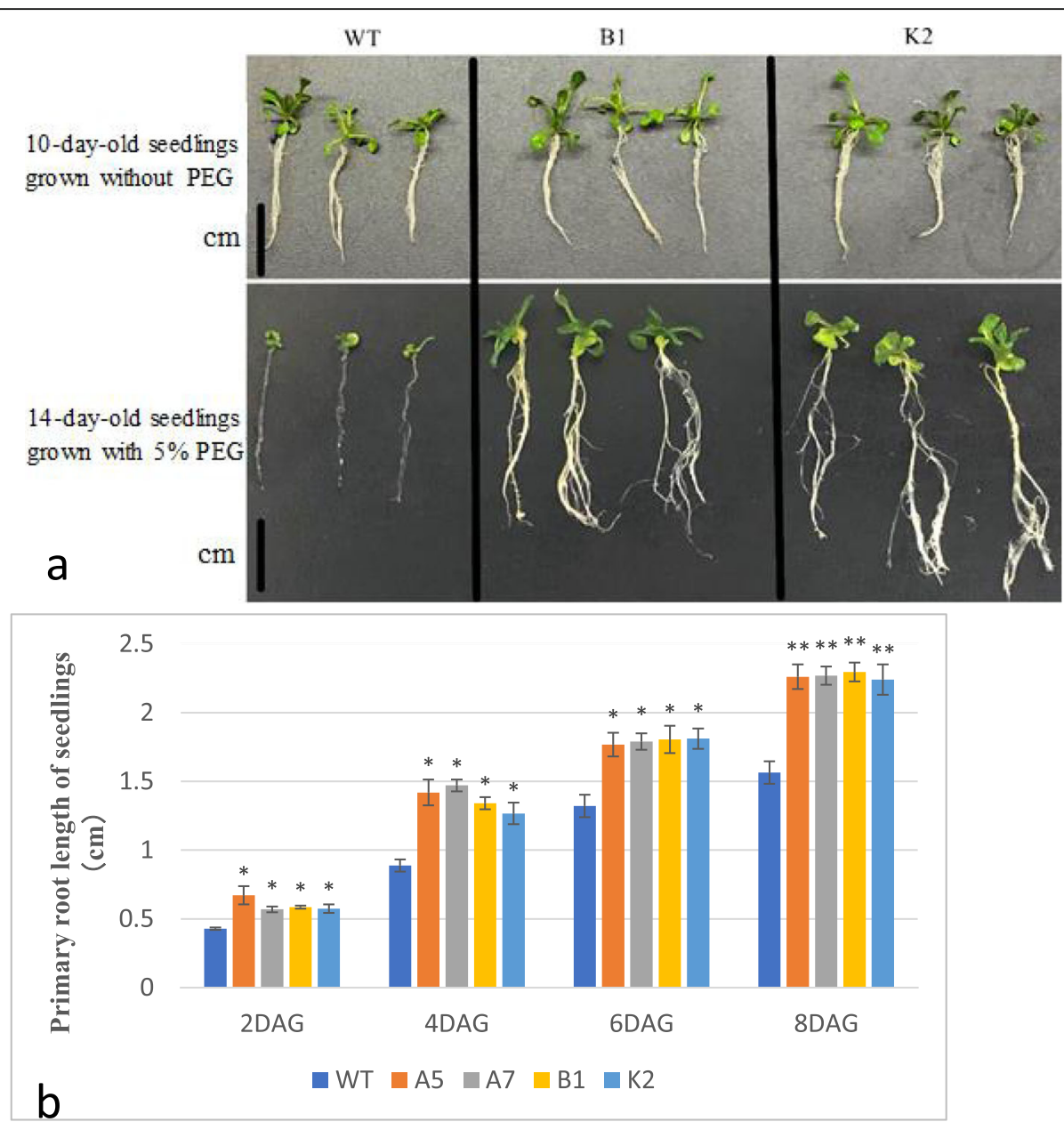

K2

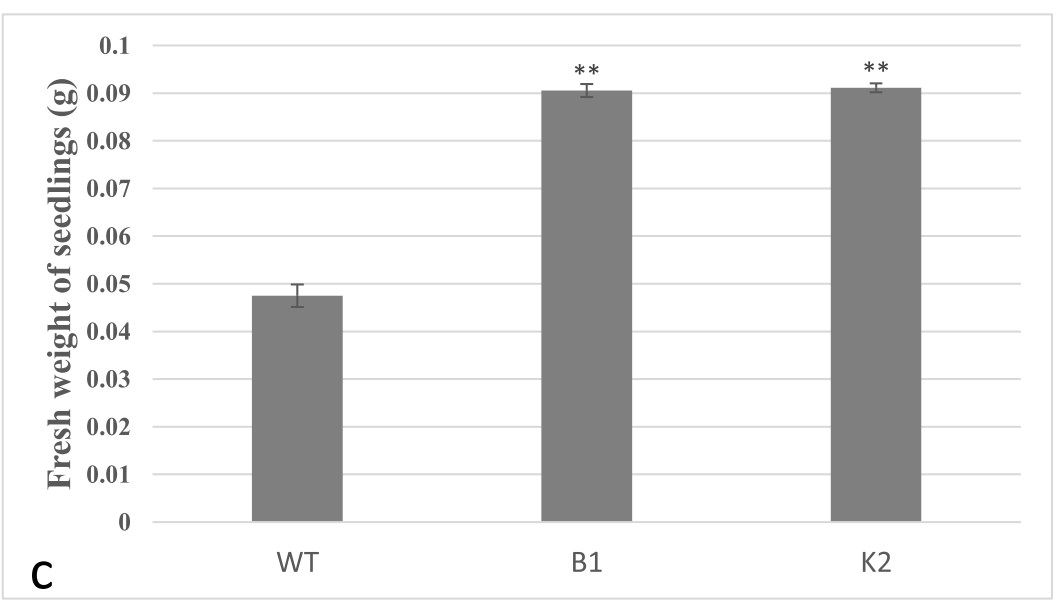

Fig. 1 a: 10-day-old WT and transgenic lines B1 and K2 seedlings without PEG stress (up) and 14-day-old seedlings of WT and transgenic lines B1 and K2 with PEG stress (down). Scale bar $=1 \mathrm{~cm}$; b: Primary root length of seedlings from WT and transgenic lines A5, A7, B1 and K2 grown on $1 /$ 2 MS agar medium added with 5\% PEG-6000; c: Fresh weight of 14-day -old seedlings from WT and transgenic lines A5, A7, B1 and K2 grown on $1 / 2 \mathrm{MS}$ agar medium added with 5\% PEG-6000; Error bars indicate \pm SD, ${ }^{* *} P<0.01,{ }^{*} P<0.05$

after 15 days of dehydration, the wilting frequency was 63.6-81.8\% in WT compared with $18.2-25 \%$ in transgenic lines (Figs. 2 and 3). After 22 days of dehydration, the stressed plants were re-watered, and the extent of recovery was determined 1 day after resumption of watering. The transgenic lines showed significantly higher recovery frequency, i.e., $58.3-63.6 \%$ compared with $18.1-36.3 \%$ in WT (Figs. 2 and 3). Based on these data, it can be concluded 


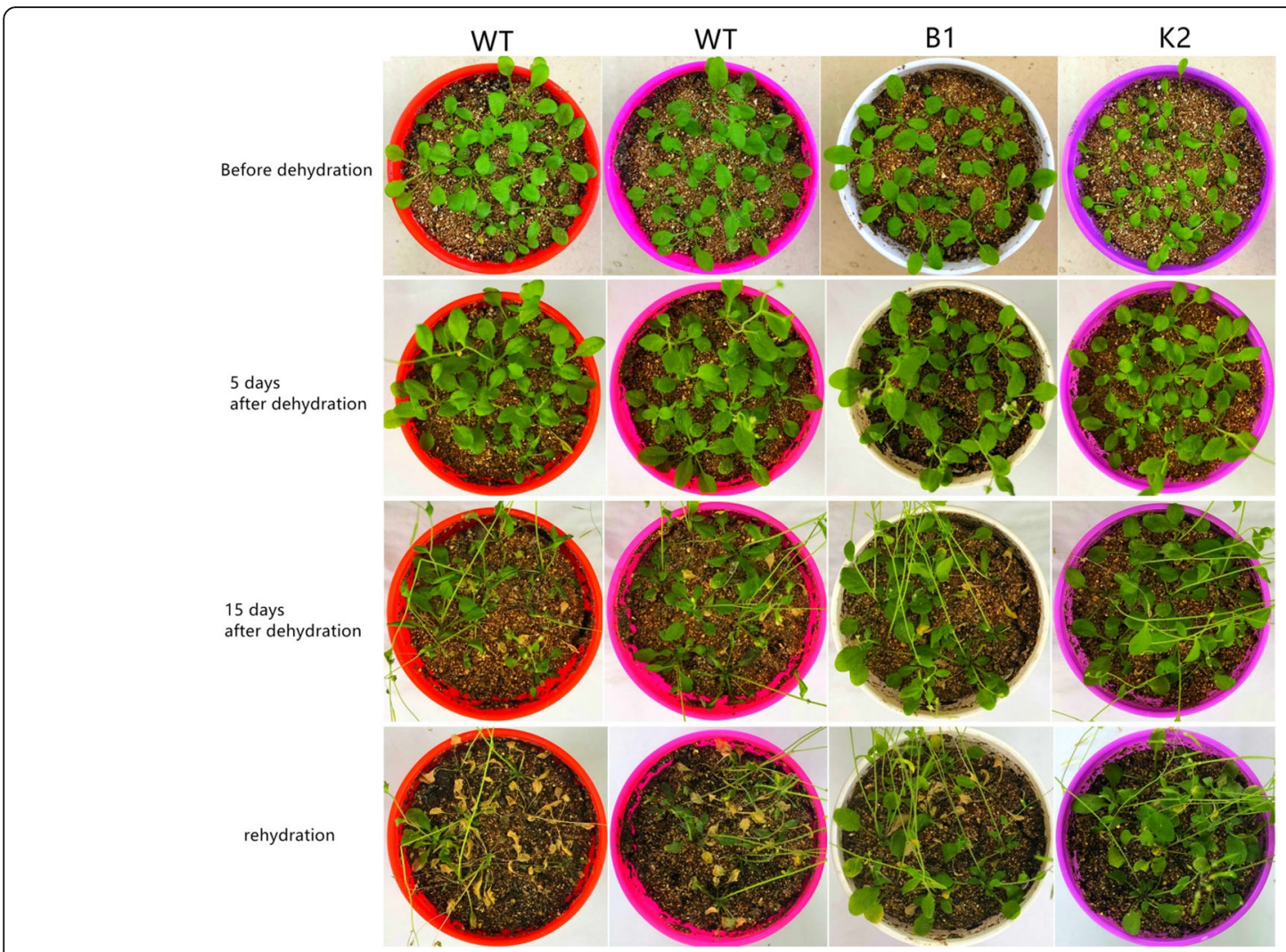

Fig. 2 Morphology of WT and transgenic lines B1 and K2 6 days before dehydration; 5 days and 15 days after dehydration; 1 day after rehydration. Before drought stress the plants were well watered

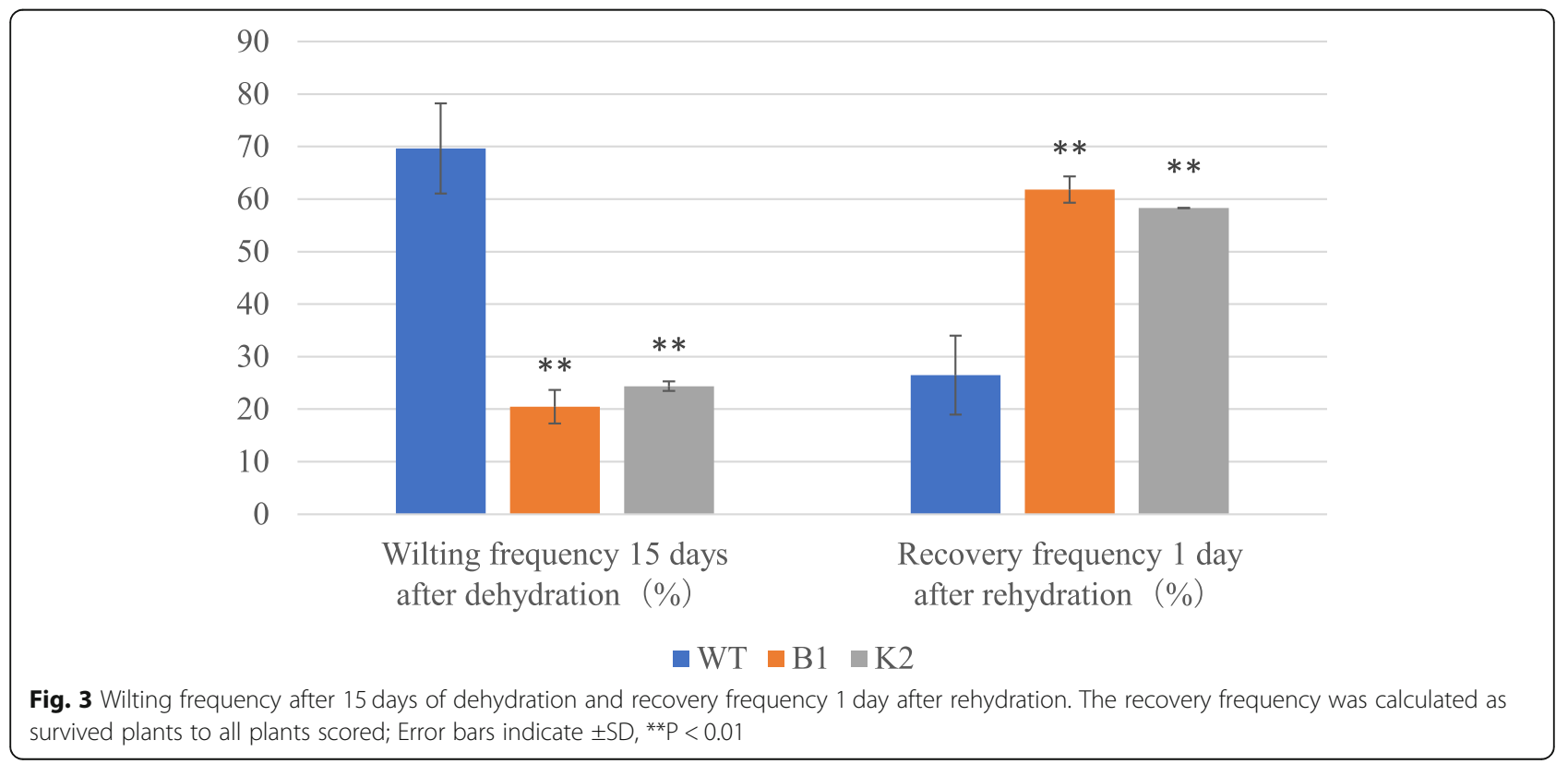


that CeWRI4 improves drought stress tolerance in Arabidopsis.

\section{Gas exchange parameters and water relations were altered in transgenic Arabidopsis lines}

In plants more than $90 \%$ of water uptake is lost through transpiration, mainly via stomata [45]. It is well documented that stomata closure is one of the first responses of plants to drought in order to avoid excessive water loss and to protect the photosynthetic machinery [46]. Control of stomatal conductance under drought is considered to be a promising approach for developing drought resistance in crops [47]. Transgenic soybean overexpressing Arabidopsis $L O S 5 / A B A 3$ exhibited reduced water loss by decreasing stomatal aperture and transpiration rate, thereby alleviating leaf wilting and maintained higher relative water content [48]. Transgenic rice expressing AtEDT1/HDG11 also exhibited increased WUE and photosynthesis by reducing stomatal conductance and transpiration [49]. In this study it was found that net photosynthesis and intercellular $\mathrm{CO}_{2}$ concentration were not significantly different between WT and transgenic lines when drought stressed (Fig. 4a-b). On the other hand, transgenic lines showed significantly lower stomatal conductance and transpiration rate compared with WT (Fig. 4c-e). Under drought stress, the stomatal conductance of transgenic B1 and K2 was 69 and 75\% of WT, respectively (Fig. 4c), while the transpiration rate was 76 and $82 \%$ of WT, respectively (Fig. 4 d). Transgenic lines exhibited higher water use efficiency, which was 150 and 130\% of WT in transgenic lines B1 and K2, respectively (Fig. $4 \mathrm{e})$. The data reported in our study is in good agreement with previous reports [50-52].

\section{Transgenic Arabidopsis plants showed slower chlorophyll} leaching and water loss

Leaves of WT and transgenic Arabidopsis seedlings were immersed in $80 \%$ ethanol to determine the chlorophyll leaching. As the time went on, more and more chlorophyll leached out in both WT and transgenic lines, however the latter showed significantly slower chlorophyll leaching compared with WT. After 105 mins, chlorophyll leaching for B1 and K2 lines was lower than 50 and 40\%, respectively, while in WT it was higher than $60 \%$ (Fig. 5a). The water loss from detached leaves was lower than $50 \%$ in transgenic lines compared with 58\% in WT after 135 mins (Fig. 5b).

\section{Expression of key genes for fatty acid and cuticular wax biosynthesis was altered in transgenic Arabidopsis lines} Cuticular wax plays important roles in protecting plants from drought stress $[6-10,53,54]$. It was shown that WRI4 activates the expression of genes involved in fatty acid elongation of wax precursors and production of wax esters by directly binding to their promoters. WRI4 also plays role in fatty acid biosynthesis by directly binding to promoters of genes like $B C C P 1$ and $B C C P 2[10,30]$. Disruption of WRI4 led to down-regulation of abovementioned genes and other fatty acid biosynthesis genes such as PKP1, PKP2, PDHE1 $\alpha$ and ENR1 [10].

Keeping in view the role of CeWRI4, and to further understand the mechanism of drought tolerance in transgenic lines, we attempted to explore the expression of key genes involved in fatty acid and cuticular wax biosynthesis. Quantitative RT-PCR data indicated that under control growth conditions the expression of fatty acid biosynthesis genes such as $P K p-\beta 1$ (plastidic pyruvate kinase beta subunit 1, At5g52920), BCCP2 (biotin carboxyl carrier protein 2, At5g15530) and PDHE1 $\alpha$ (pyruvate dehydrogenase E1 alpha, At1g01090) [28], was not significantly different between WT and transgenic Arabidopsis lines. In WT plants, PEG-induced drought stress did not significantly alter the expression of abovementioned genes as compared with its control. On the other hand, expression of $P K p-\beta 1, B C C P 2$ and $P D H E 1 \alpha$ was significantly induced by PEG treatment (130-230\%, $50-100 \%$ and $130-220 \%$ increase, respectively) in transgenic lines as compared with the respective unstressed transgenic lines (Fig. 6a-c).

We also determined the expression of a few key cuticular wax biosynthesis genes, namely LACS1 (long-chain acylcoa synthase 1, At2g47240), WSD1 (wax ester synthase/diacylglycerol acyltransferase 1, At5g37300), KCS1 (3-ketoacyl-CoA synthase 1, At1g01120), CER1 (ECERIFERUM 1, At1g02200) and CER4 (ECERIFERUM 4, At4g33790) [3033]. Under normal growth conditions, expressions of all the above mentioned genes was significantly higher in the transgenic lines compared with WT. PEG treatment did not cause significant change in expression of these gene in WT, however, in transgenic lines the gene expression was significantly induced by PEG (gene expression being 130$300 \%$, 30-80\%, 20-80\%, 10-110\%, 80-140\% higher for LACS1, WSD1, KCS1, CER1 and CER4, respectively, Fig. 6d-h). We also determined the expression of AtWRI4, a transcription factor regulating wax biosynthesis, in transgenic Arabidopsis. Under control as well as drought stress conditions, the expression of AtWRI4 was not significantly different between WT and transgenic lines (Additional file 5). The expression of DGAT1 (At2g19450), a gene involved in TAG accumulation [29], was significantly lower (10-40\% decrease) in transgenic lines compared with WT in unstressed conditions. PEG-induced drought stress did not cause significant change in expression of DGAT1 in WT, but a significant decrease (20-70\%) in expression of this gene was observed in the transgenic lines compared with both WT and transgenic control (Additional file 6). Overall, these data showed that expression of fatty acid, cuticular wax and oil synthesis genes is significantly modulated in transgenic Arabidopsis lines expressing CeWRI4. 

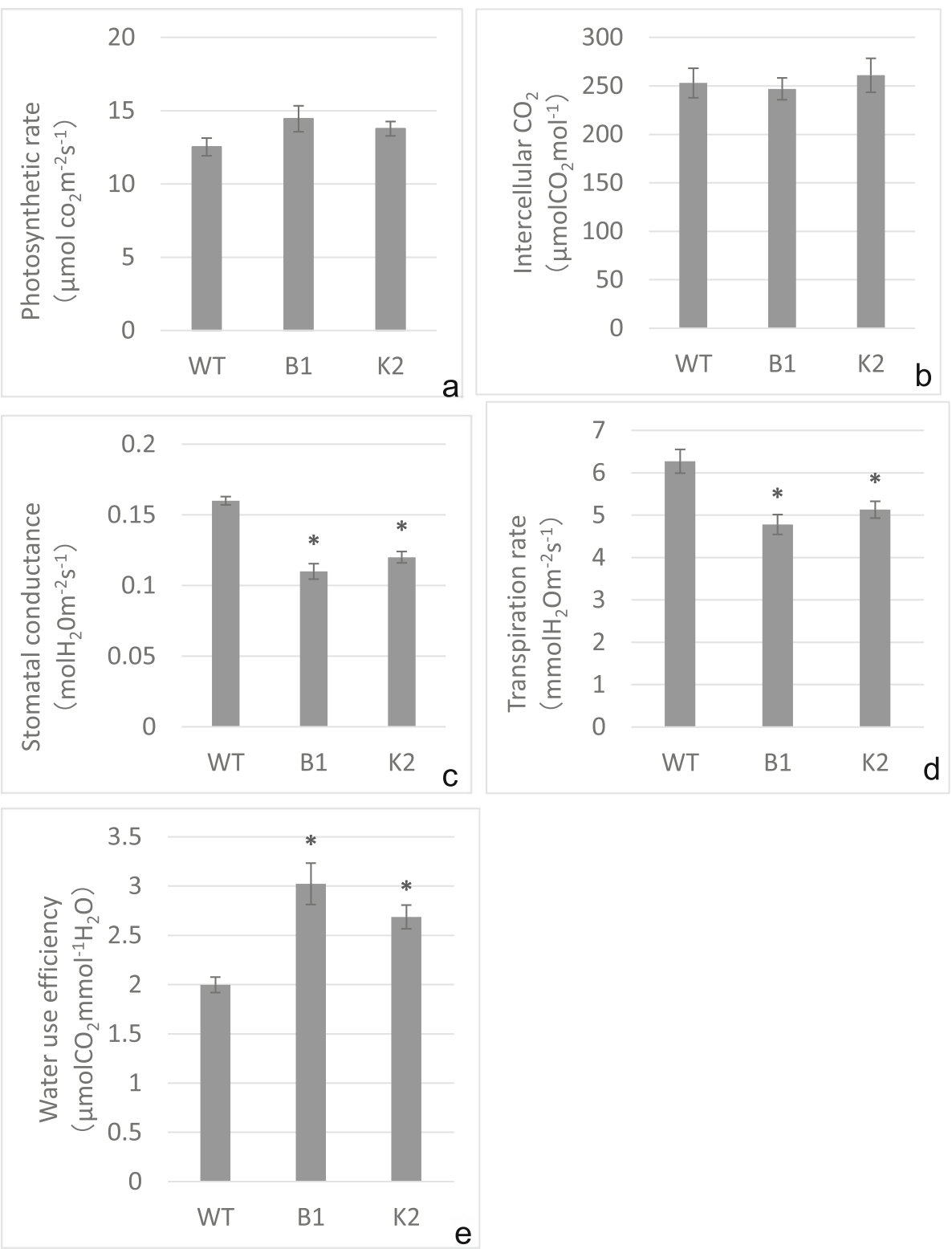

Fig. 4 Photosynthesis-related parameters measurement. 5-week-old transgenic and wild type plants grown under normal conditions were treated with 5\% PEG-6000 for 1 day. Parameters were recorded by photosynthetic system instrument at the same position of each plant. a: Photosynthetic rate of single leaf from WT, B1 and K2 plants; b: Intercellular $\mathrm{CO}_{2}$ content of single leaf from WT, B1 and K2 plants; c: Stomatal conductance of single leaf from WT, B1 and K2 plants; $\mathbf{d}$ : Transpiration rate of single leaf from WT, B1 and K2 plants; e: Water use efficiency of single leaf from WT, B1 and K2 plants. Error bars indicate $\pm \mathrm{SD},{ }^{*} \mathrm{P}<0.05$

\section{Cuticular wax load but not oil content was higher in transgenic Arabidopsis lines}

Cuticular wax is important for preventing non-stomatal water loss from the aerial parts of terrestrial plants. It is, therefore, closely correlated with plant drought resistance $[9,55]$. Overexpression of genes like SHN1/WIN1, SHINE1, MdSHINE2, WXP1, WXP2, WSD1, MYB96 and MYB94 increased drought tolerance by increasing cuticular wax biosynthesis and deposition [6-8, 16, 18, 23-26, 56]. Alkane biosynthesis is one of the key responses of plants under osmotic stress conditions [9]. It has been proposed that cuticular alkanes confer greater resistance to water diffusion than VLCFAs $[9,16]$. Seo et al. [16] overexpressed MYB96 in Arabidopsis which resulted in $\sim 8$.6-fold and $\sim 1$.6-fold increase in total wax load in transgenic leaves and stems, respectively, compared with WT. It was further shown that increase in wax was mainly due to elevated alkanes. Similarly, transgenic mulberry overexpressing AtSHINE1 also showed increased leaf surface wax load mainly due to increased alkanes in the wax components [25]. 

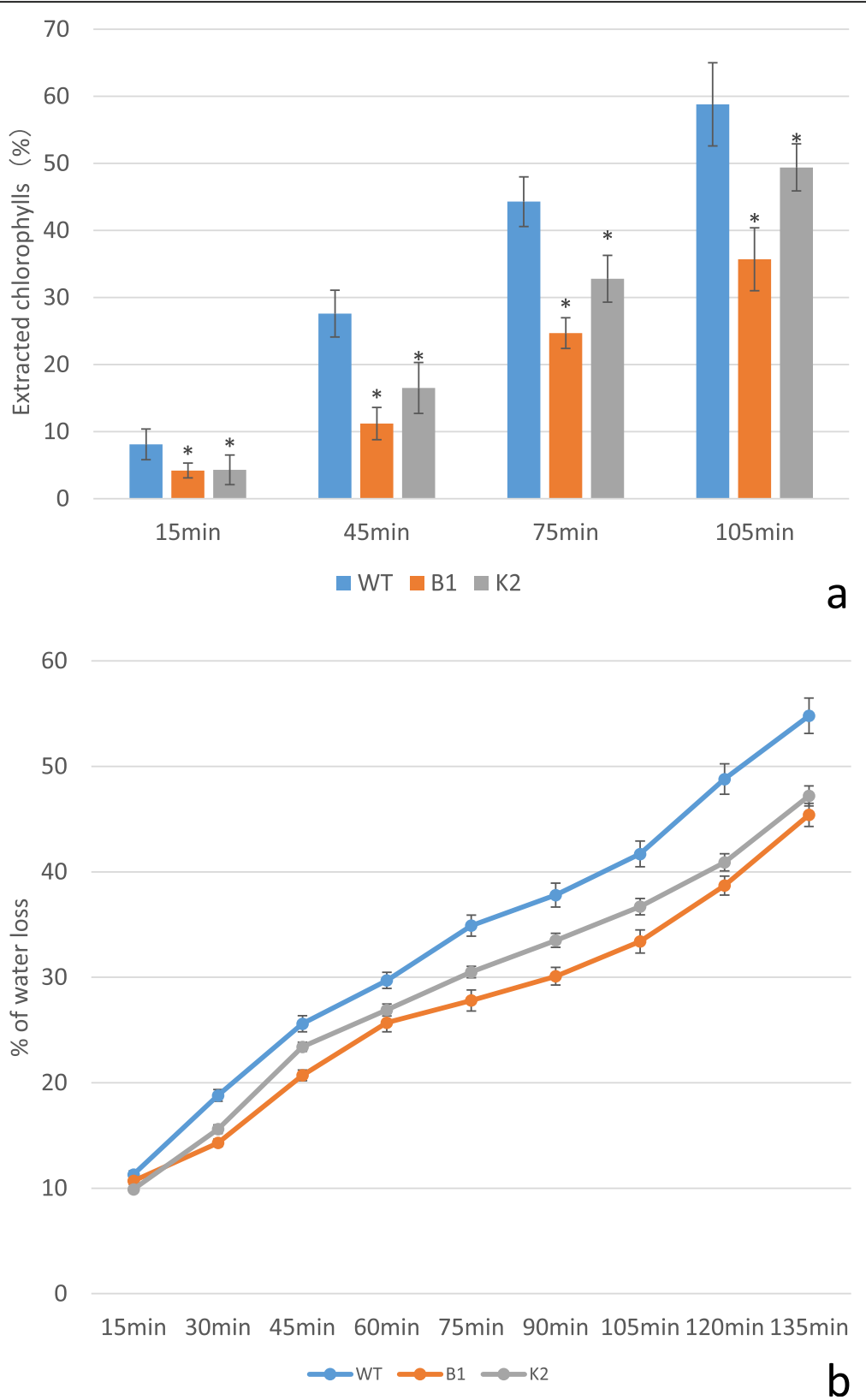

Fig. $5 \mathrm{Chl}$ extraction and water loss experiment. a: Chl extraction. Data were shown as percentage of total chlorophyll content $24 \mathrm{~h}$ after initial soaking; b: Water loss assays. Percentage of water loss was calculated as that follows: (W1-W2)/W1 (W1: Initial leaf weight before water loss; W2: Leaf weight after water loss at different time points). Error bars indicate $\pm S D$, ${ }^{*}<0.05$

In this study it was found that without drought stress, stem wax content was higher by 26 and $22 \%$ in transgenic lines $\mathrm{B} 1$ and $\mathrm{K} 2$, respectively, than WT (Fig. 7a). Among the wax components, alkanes were higher in transgenic lines than WT (31 and 26\% increase in transgenic lines $\mathrm{B} 1$ and $\mathrm{K} 2$, respectively), while other cuticular wax components were not significantly different between transgenic lines and WT (Fig. 7b). Similarly, total leaf wax load was higher by 24 and $31 \%$, respectively, in transgenic lines B1 and K2 than WT (Fig. 7d). Of the leaf waxes, alkanes were 25 and $35 \%$ higher while primary alcohols were 51 and $1.24 \%$ higher in transgenic lines B1 and $\mathrm{K} 2$, respectively, than WT. Other cuticular wax components such as aldehydes and fatty acids were not significantly different (Fig. 7e).

With drought stress stem wax load was significantly increased in transgenic B1 and K2, while leaf wax load was significantly increased in $\mathrm{K} 2$ but not in B1 (Fig. 7a, d). It was found that with drought stress total wax in stems of transgenic B1 and $\mathrm{K} 2$ was 55 and 57\% higher than that in WT (Fig. 7a), in which the alkanes were 63 

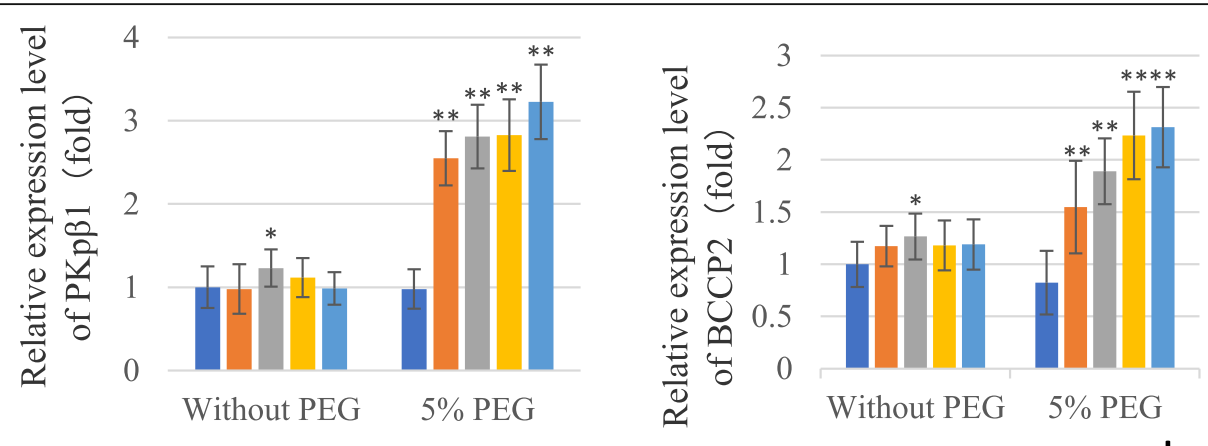

$\because \mathrm{WT}=\mathrm{A} 5 \quad \mathrm{~A} 7 \quad \mathrm{~B} 1=\mathrm{K} 2$

a
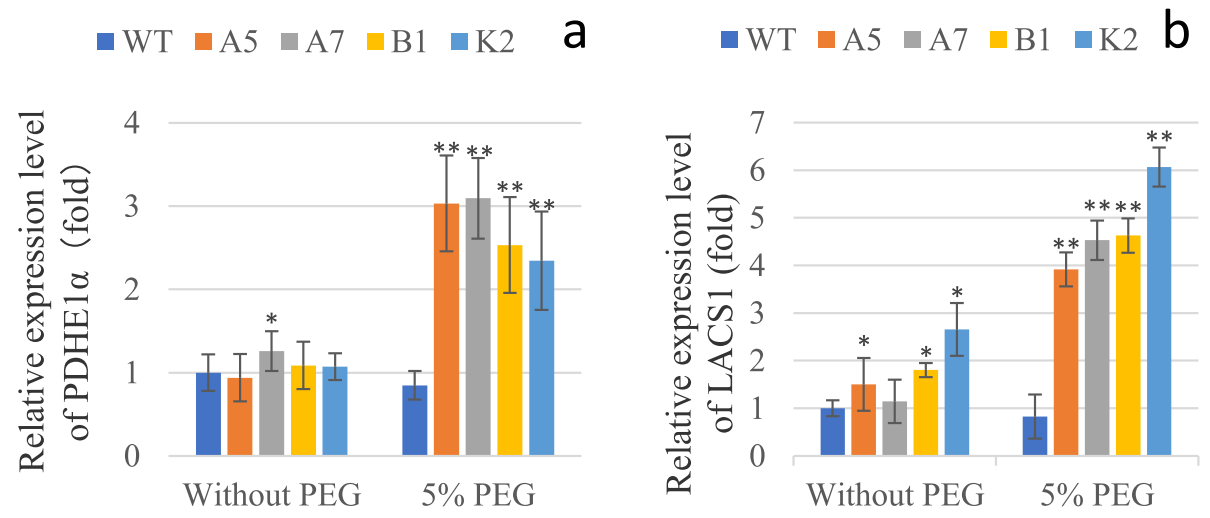

$\square \mathrm{WT}-\mathrm{A} 5 \square \mathrm{A} 7-\mathrm{B} 1-\mathrm{K} 2$

C
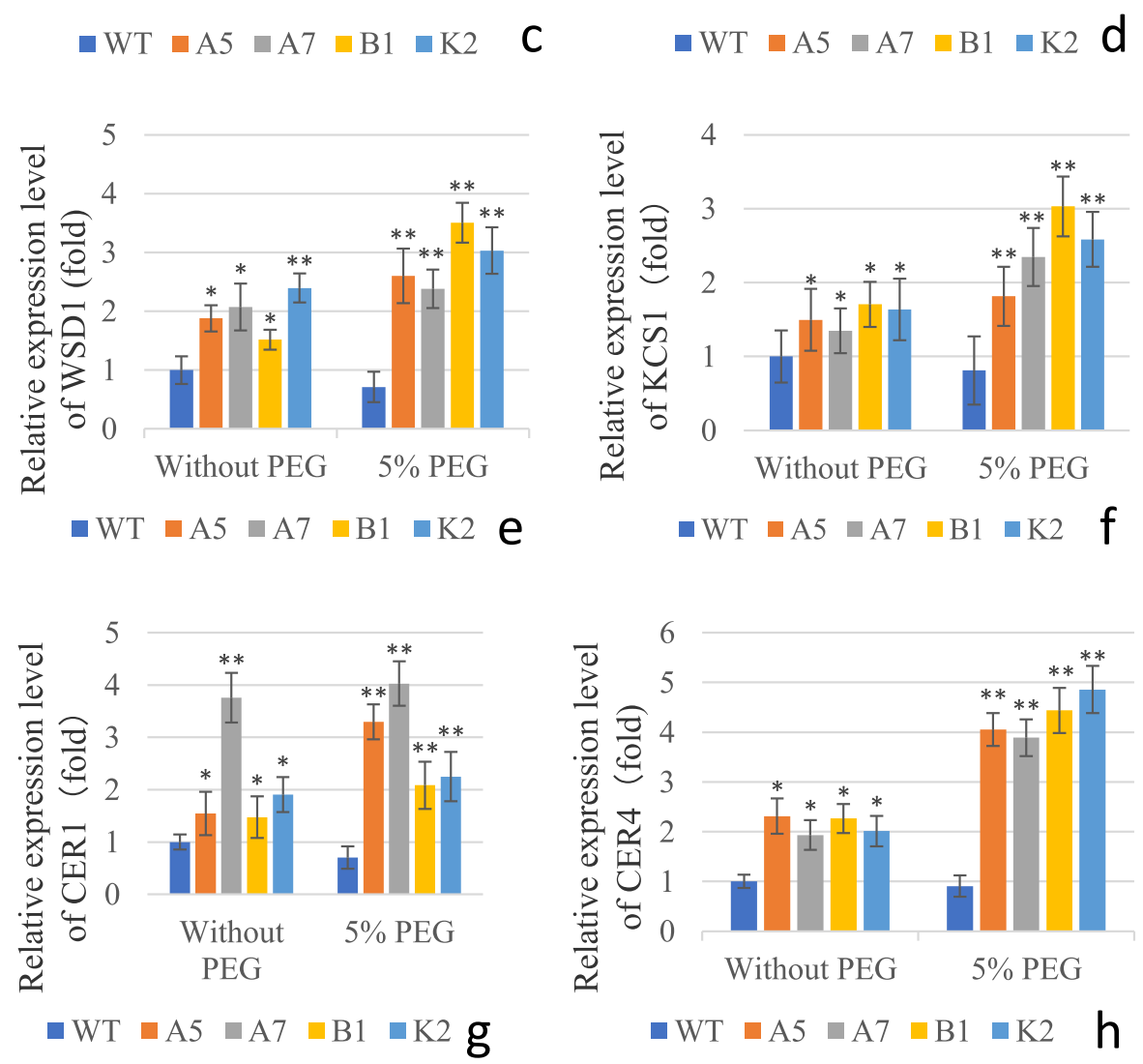

Fig. 6 qRT-PCR analysis of genes involved in fatty acids and cuticular wax biosynthesis in WT and transgenic lines A5, A7, B1, K2. Each value was calculated as the average of three independent measurements. Error bars indicate $\pm S D$, ${ }^{*} P<0.01,{ }^{*} P<0.05$ 

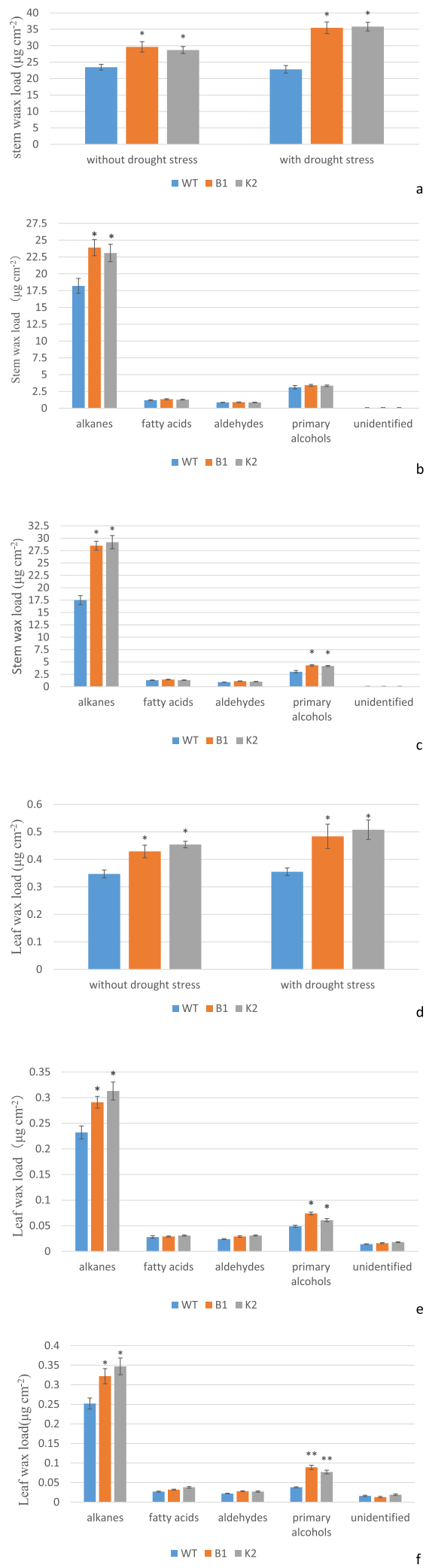

Fig. 7 Cuticular wax content and composition stems and leaves of WT and transgenic lines B1 and K2. a: Total wax load in stems of WT and transgenic lines B1 and K2 under drought stress and non-stress conditions; $\mathbf{b}$ : Cuticular wax compositions in stems of WT and transgenic lines B1 and K2 under non-stress condition; $\mathbf{c}$ : Cuticular wax compositions in stems of WT and transgenic lines B1 and K2 under drought-stress condition; $\mathbf{d}$ : Total wax load in leaves of WT and transgenic lines B1 and K2 under drought stress and non-stress conditions; e: Cuticular wax compositions in leaves of WT and transgenic lines B1 and K2 under non-stress condition. f: Cuticular wax compositions in leaves of WT and transgenic lines B1 and K2 under drought-stress condition. Error bars indicate $\pm S D$, ${ }^{*} P<0.05$

and 67\% higher in transgenic $\mathrm{B} 1$ and $\mathrm{K} 2$ than in WT, respectively, while primary alcohols were 43 and 38\% higher than that in WT leaves, respectively, and other cuticular wax components were not significantly different (Fig. 7c). Similarly, total wax load was 36 and $43 \%$ higher in transgenic B1 and K2 leaves than in WT (Fig. $7 \mathrm{~d}$ ), in which the alkanes were 28 and $38 \%$ higher in transgenic $\mathrm{B} 1$ and $\mathrm{K} 2$ than in WT, respectively, while primary alcohols were 134 and $102 \%$ higher than that in WT leaves, respectively, and other cuticular wax components such as aldehydes and fatty acids were not significantly different (Fig. 7f).

Oil content in Arabidopsis leaves was also assayed, however no significant difference was found between WT and transgenic lines (Additional file 7). This is consistent with the DGAT1 expression data. The expression of DGAT1 was significantly lower in transgenic lines compared with WT under drought stress conditions (Additional file 6). This could be the possible reason for no significant difference in oil content between WT and transgenic lines, even though the expression of genes involved in fatty acid biosynthesis was significantly higher in transgenic lines than WT (Fig. 6a-c).

\section{Epicuticular wax crystal deposition was higher in transgenic Arabidopsis leaves}

Scanning electron microscopic (SEM) analysis indicated that significantly more epicuticular wax crystals were observed on leaf surface of transgenic Arabidopsis under drought stress condition compared with WT (Fig. 8a-b). The stoma in transgenic lines remained smooth and normal while shrinking and distortion was observed in WT stoma (Fig. 8a-b). These data indicate that CeWRI4 expression in Arabidopsis significantly increased the leaf epicuticular wax crystal deposition.

Transgenic Arabidopsis plants showed significantly lower soluble sugars, free proline and MDA content under drought stress

Malondialdehyde (MDA), the product of membrane peroxidation, is considered an indicator of lipid peroxidation and membrane damage $[51,57,58]$. It has been 


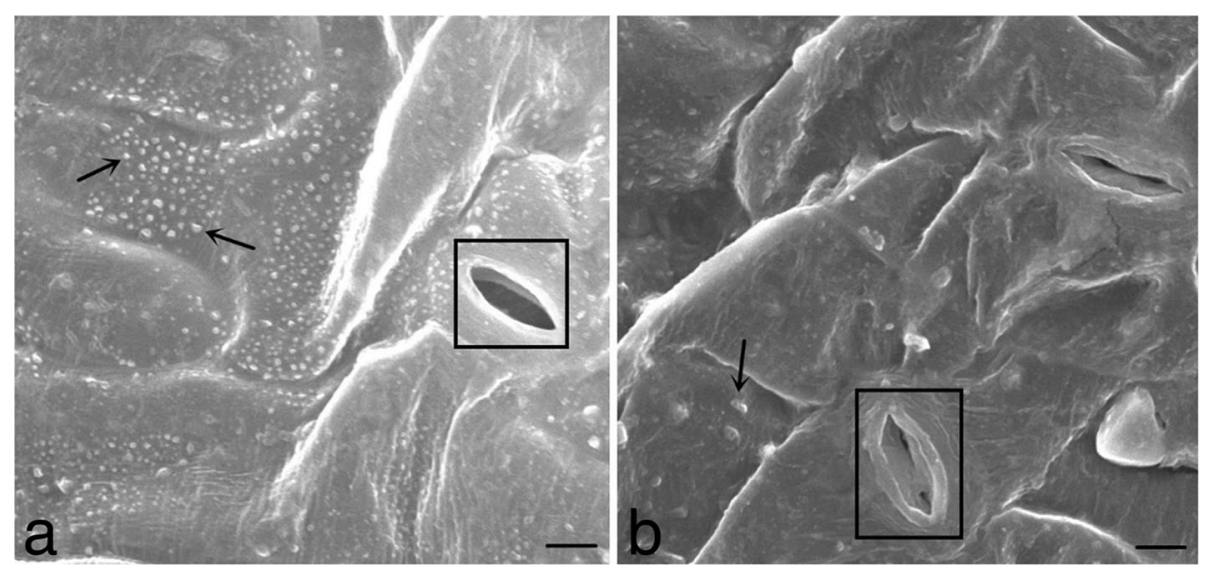

Fig. 8 SEM images of wax crystals in adaxial epidermis of 5-week-old transgenic (a) and WT (b) Arabidopsis plants after 10 days' drought stress. Epicuticular wax crystals indicated by arrows and stoma by rectangular boxes. Scale bar $=5 \mu \mathrm{m}$

observed that plants, when subjected to drought stress, accumulate osmolytes such as soluble sugars and proteins to maintain osmotic equilibrium and membrane integrity $[59,60]$. Many plants modulate their osmotic adjustment abilities to resist drought stress via accumulating proline and soluble sugars, which participate in osmotic protection [61, 62]. To gain further insights into drought tolerance phenotype of transgenic Arabidopsis expressing CeWRI4, we assayed the content of soluble sugars, free proline and MDA. After two weeks of real dehydration, the concentration of soluble sugars was significantly lower in transgenic lines as compared with WT (only 14.3$29.9 \%$ of WT, Fig. 9a). A similar trend was observed for proline and MDA content. In transgenic lines proline and MDA were also significantly lower as compared with WT (being $26.9-50.6 \%$ and $36.5-45.5 \%$ of WT contents, respectively, Fig. 9b-c). These results suggested that probably the transgenic lines suffered less lipid peroxidation and membrane damage.

\section{Conclusions}

In this study we cloned a WRI4-like gene from C. esculentus and functionally characterized it by expressing it in Arabidopsis. CeWRI4-like gene improved drought tolerance in Arabidopsis by promoting cuticular wax biosynthesis and deposition, thus lowering chlorophyll leaching, stomatal conductance, transpiration rate, water loss and increasing water use efficiency under drought stress. CeWRI4 could be a valuable target for genetic manipulation to improve drought tolerance of commercially important crops.

\section{Methods}

Plant materials and treatments

Arabidopsis thaliana ecotype Columbia and tubers of Cyperus esculentus (yellow nutsedge) cv. Hubu-1 were provided by State Key Laboratory of Biocatalysis, College of Life Sciences, Hubei University, China. The yellow nutsedge tubers were germinated at $22{ }^{\circ} \mathrm{C}$ under a $16 \mathrm{~h}$ light $/ 8 \mathrm{~h}$ dark cycle. RNA was isolated from leaves, roots and fresh tubers as described by Cheng et al. [63].

\section{Cloning of WRI4 from yellow nutsedge}

WRI1 protein sequences from different plant species (Solanum tuberosum, accession No.: AAA66057; Nicotiana tabacum, accession No.: ABD60582; Fragaria $x$ ananassa, accession No.: AAS00541; Gladiolus hybrid cultivar, accession No.: AHN15416; Triticum aestivum, accession No.: AAF61173; Hordeum vulgare, accession No.: AAU06191; https://www.ncbi.nlm.nih.gov/) were aligned by ClustalW2 (http://www.ebi.ac.uk/Tools/msa/clustalw2/). Degenerate primers (Additional file 1) based on conserved region were used to amplify the conserved region of CeWRI-like gene using cDNAs from leaf, root, and tuber as templates. SMAR T RACE Amplification kit (Clontech Laboratories, Mountain View, CA) was used to clone $5^{\prime}$ and $3^{\prime}$ fragments of the CeWRI-like gene. Full length cDNA sequence was cloned by using primers based on RACE results (Additional file 1).

\section{Sequence and phylogenetic analyses}

In order to find ORFs and to deduce amino acid sequence, open reading frame (ORF) Finder (http://www. ncbi.nlm.nih.gov/gorf/gorf.html) tool was used. NCBI CD-Search tool (http://www.ncbi.nlm.nih.gov/Structure/ cdd/wrpsb.cgi) was applied for finding conserved domains in the deduced CeWRI-like protein. Phylogenetic tree of the two-AP2-domain-containing genes was generated by neighbor joining method (with 1000 bootstrap replicates) using MEGA 7.0 software [64].

\section{Construction of CeWRI4 over-expression vector and genetic transformation of Arabidopsis thaliana}

A PCR product of $1423 \mathrm{bp}$ containing complete ORF of CeWRI4 was digested with PstI and SalI and then placed 


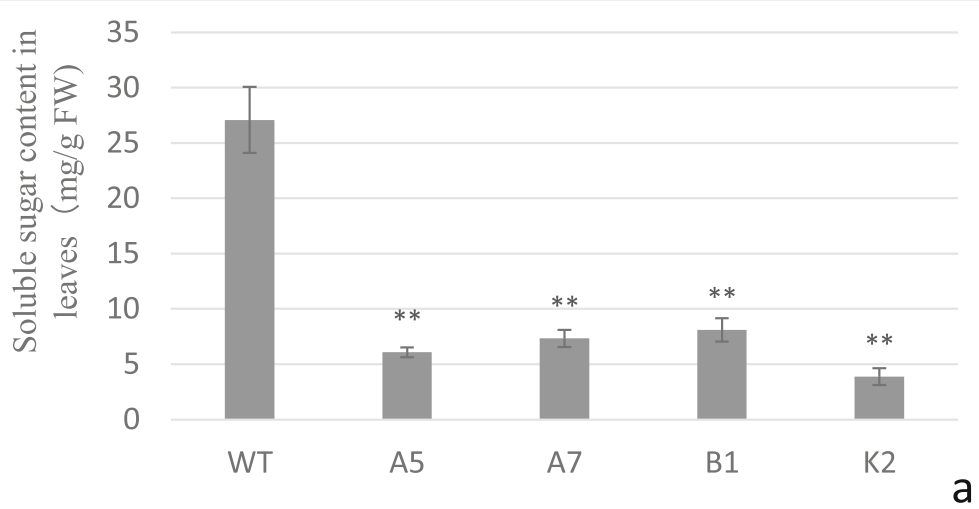

90

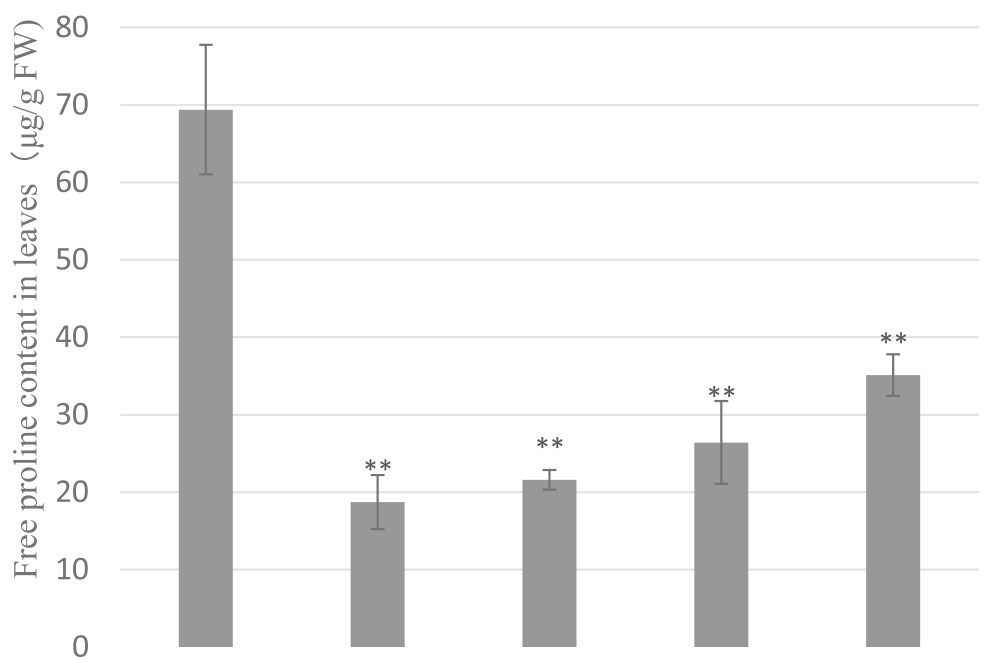

WT

A5

A7

B1

$\mathrm{k} 2 \mathrm{~b}$

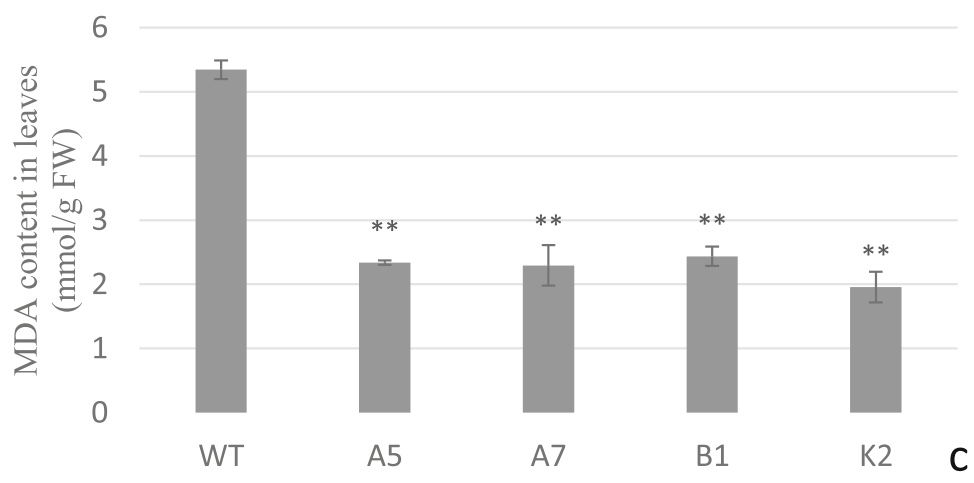

Fig. 9 Physiological indices in WT and transgenic Arabidopsis lines A5, A7, B1 and K2 grown with water deprivation. a Soluble sugar content in leaves; $\mathbf{b}$ Free proline content in leaves; C. MDA content in leaves. Error bars indicate $\pm S D$, ${ }^{* *} P<0.01$ 
between CaMV 35S (35S) promoter and nos terminator of pCambia 2300-35S-nos [65] to construct vector pCambia 2300-35S-CeWRI4-nos. Sequencing was performed to ensure that the construct was correct.

WT Arabidopsis seeds were surface sterilized and grown on 1/2 Murashige and Skoog (MS) agar plates containing $3 \%$ sucrose in a growth chamber set to $16 \mathrm{~h}$ light $/ 8 \mathrm{~h}$ dark $\left(70-80 \mathrm{~lm} / \mathrm{m}^{2} / \mathrm{s}\right)$ at $22^{\circ} \mathrm{C}$ after 2 days of stratification at $4{ }^{\circ} \mathrm{C}$. Fifteen-day-old plants were transferred onto soil and grown in a growth chamber at $16 \mathrm{~h}$ light $/ 8 \mathrm{~h}$ dark $(70-80$ $\mathrm{lm} / \mathrm{m}^{2} / \mathrm{s}$ ) at $22^{\circ} \mathrm{C}$. The pCambia 2300-35S-CeWRI4-nos vector was introduced into Agrobacterium tumefaciens EHA105 which was then used to transform Arabidopsis by floral-dip method [66]. Transgenic plants (T1, T2, T3) were PCR-confirmed by using NPT II and CeWRI4 gene specific primers (Additional file 1).

\section{Drought tolerance assessment}

For PEG-simulated drought tolerance assessment, WT and transgenic Arabidopsis seeds were sown on 1/2 MS agar medium with/without 5\% PEG-6000. Germination rate of the WT and transgenic Arabidopsis were scored 6 days after seed sowing. The length of the primary roots was recorded on 2, 4, 6, 8 days after seed germination. Three biological repeat groups were set for each line, each group containing 10 repeat seedlings. For imposing real dehydration stress, two-week-old seedlings, previously germinated on $1 / 2$ MS medium, were transplanted into pots $(12 \times 12$ $\mathrm{cm}$ ) filled with a mixture of nutrient soil and vermiculite (1: 1 ratio). The pots were kept at $22^{\circ} \mathrm{C}$ at a 16 -h light/ 8-h dark photoperiod. Three biological repeat pots were set for each line, with each pot containing 10 repeat seedlings. Prior to the onset of dehydration stress, the plants were regularly watered and photographed. 20-day-old Arabidopsis plants kept under normal growth condition were given dehydration stress by withholding water. Wilting frequency was determined 15 days after the onset of dehydration stress. Watering was resumed after 22 days of dehydration. Next day, the recovery frequency was scored as the number of surviving plants out of the total plants.

\section{Water loss measurement}

Rosette leaves of 5-week-old seedlings were detached and placed in petri dishes and air-dried to measure transpirational water loss. Weights of detached leaves were measured at different time points during dark exposure. Percentage of water loss was calculated as that follows: (W1-W2)/W1 (W1: Initial leaf weight before water loss; W2: Leaf weight after water loss at different time points).

\section{Chlorophyll leaching assay}

Rosette leaves of 5-week-old Arabidopsis seedlings were immersed in $5 \mathrm{ml}$ of $80 \%$ ethanol at room temperature (gently agitating in the dark) for chlorophyll leaching assays. $1 \mathrm{ml}$ of aliquot was taken out at $15,45,75$, and $105 \mathrm{~min}$ for chlorophyll quantification using a UNICO 7202B spectrophotometer (USA) at wavelengths of 663 and $645 \mathrm{~nm}$.

\section{Physiological analyses of transgenic and WT Arabidopis plants}

For measuring photosynthesis-related parameters, 5week-old transgenic and WT plants were treated with 5\% PEG-6000 for 1 day, then Li-6400 photosynthetic system instrument (LI-COR, Inc. Lincoln, USA) was used to measure the rate of stomatal conductance $\left(\mathrm{g}_{\mathrm{s}}\right)$, transpiration $\left(T_{r}\right)$, photosynthesis $\left(P_{n}\right)$ for leaves of different plants at the same position as described by Wei et al. [67]. Water use efficiency of single leaf (WUE) was calculated as that follows: WUE = photosynthetic rate / transpiration rate.

20-day-old Arabidopsis plants kept under normal growth condition were given dehydration stress by withholding water for 15 days. At the end of the treatment, leaves of transgenic lines and WT were harvested for measurement of MDA, free proline and soluble sugars. For determination of leaf MDA content, thiobarbituric acid method was used as described by Dhindsa and Matowe [68]. Leaf free proline and soluble sugars content was assayed using methods described by Troll and Lindsley [69] and Flood and Priestley [70], respectively.

\section{Wax extraction and GC-MS analysis}

Oil and cuticular waxes were extracted from both leaves and stems of 5 to 6-week-old WT and transgenic Arabidopsis as described by Park et al. [10]. The quantifications were carried out by a GC-MS-QP2010 (Plus) gas chromatograph equipped with flame ionization detector (GC2010, Shimazu, Tokyo, Japan). Retention times and temperatures for GC were programmed as described by Lee and Suh [18]. Wax composition was determined by comparing peak retention times with those of reference standards. Wax loads were estimated by quantifying the areas of major peaks in comparison with the internal standard. Wax load per unit leaf area and stem area was calculated based on the area of leaves and stems used for wax extraction.

\section{SEM analysis of deposition of epicuticular wax crystals on Arabidopsis leaves}

5-week-old WT and transgenic Arabidopsis plants were drought-stressed for 10 days by withholding water. Mature rosette leaves were sliced into $0.5 \mathrm{~cm}$ sections and then fixed in 5\% glutaraldehyde and coated with gold particles by using an EICO IB.5 ION coater (Tokyo, Japan). Epicuticular wax crystals on adaxial side of leaves were observed by using JEOLJSM-3690LV scanning electron microscope (Tokyo, Japan). 


\section{RNA extraction and real-time quantitative reverse transcription qRT-PCR}

Drought stress was applied to 24-day-old WT and transgenic Arabidopsis plants by treatment with 5\% PEG6000 for $10 \mathrm{~h}$. Control plants were watered without addition of PEG. Rosette leaves from control and treated plants were collected, snap frozen in liquid nitrogen, and stored at $-80^{\circ} \mathrm{C}$. Total RNA was extracted by using the Biospin Plant Total RNA Extraction Kit (Bioflux). To remove any contaminating DNA, the samples were treated with RNase-free DNase (Bioflux). cDNA was synthesized by using the PrimeScript RT reagent Kit (TAKARA). Gene expression was determined by qRT-PCR on Stratagene Mx3005P quantitative PCR system (Agilent Technologies) using BioEasy Master Mix SYBR Green (BIOER). The sequence of the primers used in qRTPCRs is given in Additional file 1. Specific primer pairs with $100 \%$ efficiency and single peaks were selected. ACTIN2 (At3g18780) was used as reference gene for normalizing the expression. Relative gene expression was calculated by the comparative threshold cycle method.

\section{Statistical analysis}

All experiments were carried out with three replicates. Significant differences were detected by $t$ tests using the SPSS software $\left({ }^{*} P<0.05 ;{ }^{* *} P<0.01\right)$.

\section{Supplementary information}

Supplementary information accompanies this paper at https://doi.org/10. 1186/s12870-020-02707-7.

Additional file 1. Table S1 Primers for PCR and qRT-PCR.

Additional file 2 Figure S1 Coding sequence and deduced protein of yellow nutsedge CeWRI4. The start and stop codons are marked by black bars.

Additional file 3. Figure S2 Phylogenetic tree of the two-AP2-domaincontaining genes from different plant species.

Additional file 4 Figure S3 Relative expression of CeWR/4 in different nutsedge tissues. Fresh and tender leaves, roots and tubers were collected from plants growing in the field for RNA extraction and q-PCR.

Additional file 5 Figure S4 Relative expression of internal AtWRI4. 24day-old WT and transgenic Arabidopsis plants were treated with 5\% PEG6000 for $10 \mathrm{~h}$. Rosette leaves were harvested for RNA extraction and qPCR

Additional file 6 Figure S5 qRT-PCR analysis of DGAT1 involved in oil accumulation in WT and transgenic lines A5, A7, B1, K2: 24-day-old WT and transgenic Arabidopsis plants were treated with 5\% PEG-6000 for $10 \mathrm{~h}$. Rosette leaves were harvested for RNA extraction and q-PCR. Error bars indicate $\pm \mathrm{SD},{ }^{*} P<0.01,{ }^{*} P<0.05$.

Additional file 7. Figure S6 Oil content in leaves of WT and transgenic Arabidopsis grown under normal condition. Ten leaves per replicate were used for measuring weights. Error bars indicate \pm SD.

\section{Abbreviations}

APETALA2/EREBP: Ethylene Responsive Element Binding Protein; BCCP2: Biotin carboxyl carrier protein 2; BSTFA: Bis-N, N trimethylsilyl trifluoroacetamide; CER1: ECERIFERUM 1; CER4: ECERIFERUM 4; Chl: Chlorophyll; CoAs: Coenzyme As; DAG: Days after germination; DGAT1: Diacylglycerol acyltransferase 1; FW: Fresh weight; GC-MS: Gas
Chromotography-Mass spectrometry; KCS1: 3-ketoacyl-CoA synthase 1; LACS1: Long-chain acyl-coA synthase 1; MDA: Malondialdehyde; MS: Murashige and Skoog; PDHE1a: Pyruvate dehydrogenase E1 alpha; PEG: Polyethylene glycol; PKp- $\beta$ 1: Plastidic pyruvate kinase beta subunit 1; qRT-PCR: Quantitative reverse transcription Polymerase Chain Reaction; q-RTPCR: Quantitative RT-PCR; RACE: Rapid amplification of CDNA ends; SEM: Scanning electron microscopy; TAG: Triacylglycerol; UTR: Untranslated region; VLCFAs: Very-long-chain fatty acids; WSD1: Wax ester synthase/ diacylglycerol acyltransferase 1; WT: Wild type; WUE: Water use efficiency

\section{Acknowledgements}

Thanks to Dr. Juan Lin of Fudan University, China, for providing some monocot AP2/EREBP amino acid sequences.

\section{Authors' contributions}

$\mathrm{BH}, \mathrm{XZ}$ and $\mathrm{JH}$ conceived the experiments and finalized the paper, CC performed most of the experiments and prepared the draft manuscript, $\mathrm{SH}$, $\mathrm{YH}, \mathrm{DX}, \mathrm{B}-\mathrm{L} H$ and WW helped with material preparation, drought tolerance determination, qRT-PCRs and data analyses. All authors read and approved the final manuscript.

\section{Funding}

Gene cloning, Arabidopsis transformation and molecular analyses in this study were financially supported by the National Key Research and Development Program of China (2016YFD0100202-23; 2017YFD0101701I); drought tolerance assessment and data analyses were supported by the National Natural Science Foundation of China (31771829). The funding bodies had no role in study design, data collection, analysis and interpretation, decision to public, or writing of the manuscript.

\section{Availability of data and materials}

The datasets supporting results of this study are included in the manuscript and additional supporting files. The sequence for C. esculentus WR/4 is deposited and available in NCBI Genbank as accession MW039149.

Ethics approval and consent to participate

Not Applicable.

\section{Consent for publication}

Not applicable.

\section{Competing interests}

The authors declare that they have no competing interests.

\section{Author details}

${ }^{1}$ State Key Laboratory of Biocatalysis and Enzyme Engineering, College of Life Science, Hubei University, Wuhan 430062, China. ${ }^{2}$ Biotechnology Department, COMSATS University Islamabad, Abbottabad Campus 22060, University Road, Abbottabad, Pakistan. ${ }^{3}$ Hubei Key Laboratory of Waterlogging Disaster and Agricultural Use of Wetland, Yangtze University, Jingzhou 434023, China.

Received: 22 November 2019 Accepted: 19 October 2020 Published online: 31 October 2020

\section{References}

1. Barthlott W, Neinhuis C. Purity of the sacred lotus, or escape from contamination in biological surfaces. Planta. 1997;202(1):1-8.

2. Eigenbrode SD, Espelie KE. Effects of plant Epicuticular lipids on insect herbivores. Annu Rev Entomol. 1995;40(1):171-94.

3. Reicosky DA, Hanover JW. Physiological effects of surface waxes: I. light reflectance for Glaucous and Nonglaucous Picea pungens. Plant Physiol. 1978;62(1):101-4.

4. Solovchenko A, Merzlyak M. Optical properties and contribution of cuticle to UV protection in plants: experiments with apple fruit. Photochem Photobiol Sci. 2003;2(8):861-6.

5. Riederer M, Schreiber L. Protecting against water loss: analysis of the barrier properties of plant cuticles. J Exp Bot. 2001;52(363):2023-32.

6. Aharoni A, Dixit S, Jetter R, Thoenes E, van Arkel G, Pereira A. The SHINE clade of AP2 domain transcription factors activates wax biosynthesis, alters 
cuticle properties, and confers drought tolerance when overexpressed in Arabidopsis. Plant Cell. 2004;16(9):2463-80

7. Zhang JY, Broeckling CD, Blancaflor EB, Sledge MK, Sumner LW, Wang ZY. Overexpression of WXP1, a putative Medicago truncatula AP2 domaincontaining transcription factor gene, increases cuticular wax accumulation and enhances drought tolerance in transgenic alfalfa (Medicago sativa). Plant J. 2005;42(5):689-707

8. Zhang JY, Broeckling CD, Sumner LW, Wang ZY. Heterologous expression of two Medicago truncatula putative ERF transcription factor genes, WXP1 and WXP2, in Arabidopsis led to increased leaf wax accumulation and improved drought tolerance, but differential response in freezing tolerance. Plant Mol Biol. 2007;64(3):265-78.

9. Kosma DK, Bourdenx B, Bernard A, Parsons EP, Lü S, Joubès J, Jenks MA. The impact of water deficiency on leaf cuticle lipids of Arabidopsis. Plant Physiol. 2009;151(4):1918-29.

10. Park CS, Go YS, Suh MC. Cuticular wax biosynthesis is positively regulated by WRINKLED4, an AP2/ERF-type transcription factor, in Arabidopsis stems. Plant J. 2016;88(2):257-70.

11. Post-Beittenmiller D. Biochemistry and molecular biology of wax production in plants. Annu Rev Plant Physiol Plant Mol Biol. 1996;47:405-30.

12. Kunst L, Samuels AL. Biosynthesis and secretion of plant cuticular wax. Prog Lipid Res. 2003;42(1):51-80.

13. Samuels $L$, Kunst $L$, Jetter R. Sealing plant surfaces: cuticular wax formation by epidermal cells. Annu Rev Plant Biol. 2008;59:683-707.

14. Li-Beisson Y, Shorrosh B, Beisson F, Andersson M, Arondel V, Bates P, Baud S, Bird D, DeBono A, Durrett T, Franke RB, Graham IA, Katayama K, Kelly AA, Larson T, Markham JE, Miquel M, Molina I, Nishida I, Rowland O, Samuels L, Schmid KM, Wada H, Welti R, Xu C, Zallot R, Ohlrogge J. Acyl-lipid metabolism. Arabidopsis Book. 2010;8:e0133.

15. Bernard A, Domergue F, Pascal S, Jetter R, Renne C, Faure JD, Haslam RP Napier JA, Lessire R, Joubès J. Reconstitution of plant alkane biosynthesis in yeast demonstrates that Arabidopsis ECERIFERUM1 and ECERIFERUM3 are core components of a very-long-chain alkane synthesis complex. Plant Cell. 2012;24(7):3106-18.

16. Seo PJ, Lee SB, Suh MC, Park MJ, Go YS, Park CM. The MYB96 transcription factor regulates cuticular wax biosynthesis under drought conditions in Arabidopsis. Plant Cell. 2011;23(3):1138-52.

17. Go YS, Lee SB, Kim HJ, Kim JY, Suh MC. A bifunctional AP2/ERF-type transcription factor represses cuticular wax biosynthesis and activates dark inducible genes under dark conditions in Arabidopsis. In: 20th international symposium on plant lipids, Seville, Spain; 2012. p. 60.

18. Lee SB, Suh MC. Cuticular wax biosynthesis is up-regulated by the MYB94 transcription factor in Arabidopsis. Plant Cell Physiol. 2015;56(1):48-60.

19. Wu R, Li S, He S, Wassmann F, Yu C, Qin G, Schreiber L, Qu L, Gu H. CFL1, a WW domain protein, regulates cuticle development by modulating the function of HDG1, a class IV homeodomain transcription factor, in rice and Arabidopsis. Plant Cell. 2011;23(9):3392-411.

20. Lam P, Zhao L, McFarlane HE, Aiga M, Lam V, Hooker TS, Kunst L. RDR1 and SGS3, components of RNA-mediated gene silencing, are required for the regulation of cuticular wax biosynthesis in developing inflorescence stems of Arabidopsis. Plant Physiol. 2012;159(4):1385-95.

21. Lam P, Zhao L, Eveleigh N, Yu Y, Chen X, Kunst L. The exosome and transacting small interfering RNAs regulate Cuticular wax biosynthesis during Arabidopsis inflorescence stem development. Plant Physiol. 2015;167(2):323.

22. Lü S, Zhao H, Des Marais DL, Parsons EP, Wen X, Xu X, Bangarusamy DK, Wang G, Rowland O, Juenger T, Bressan RA, Jenks MA. Arabidopsis ECERIFER UM9 involvement in cuticle formation and maintenance of plant water status. Plant Physiol. 2012;159(3):930-44.

23. Broun $P$, Poindexter $P$, Osborne E, Jiang CZ, Riechmann JL. WIN1, a transcriptional activator of epidermal wax accumulation in Arabidopsis. Proc Natl Acad Sci U S A. 2004;101(13):4706-11.

24. Lee SB, Kim H, Kim RJ, Suh MC. Overexpression of Arabidopsis MYB96 confers drought resistance in Camelina sativa via cuticular wax accumulation. Plant Cell Rep. 2014:33(9):1535-46.

25. Sajeevan RS, Nataraja KN, Shivashankara KS, Pallavi N, Gurumurthy DS, Shivanna MB. Expression of Arabidopsis SHN1 in Indian mulberry (Morus indica $\mathrm{L}$.) increases leaf surface wax content and reduces Post-harvest water loss. Front. Plant Sci. 2017:8:418.

26. Zhang YL, Zhang CL, Wang GL, Wang YX, Qi CH, You CX, Li YY, Hao YJ. Apple AP2/EREBP transcription factor MdSHINE2 confers drought resistance by regulating wax biosynthesis. Planta. 2019;249(5):1627-43.
27. Riechmann JL, Meyerowitz EM. The AP2/EREBP family of plant transcription factors. Biol Chem. 1998;379(6):633-46.

28. Cernac A, Benning C. WRINKLED1 encodes an AP2/EREB domain protein involved in the control of storage compound biosynthesis in Arabidopsis. Plant J. 2004;40(4):575-85.

29. Shigyo M, Hasebe M, Ito M. Molecular evolution of the AP2 subfamily. Gene. 2006;366(2):256-65.

30. To A, Joubès J, Barthole G, Lécureuil A, Scagnelli A, Jasinski S, Lepiniec L, Baud S. WRINKLED transcription factors orchestrate tissue-specific regulation of fatty acid biosynthesis in Arabidopsis. Plant Cell. 2012;24(12):5007-23.

31. Villaseñor J, Espinosa-García F. The alien flowering plants of Mexico. Divers Distrib. 2004;10:113-23.

32. Acevedo P, Strong M. Catalogue of seed plants of the West Indies. Smithson Contrib Bot. 2012;98:1192.

33. DAISIE. Delivering Alien Invasive Species Inventories for Europe. European Invasive Alien Species Gateway. 2014; www.europe-aliens.org/default.do.

34. Govaerts R, Simpson DA, Bruhl JJ, Egorova T, KL W. World checklist of Cyperaceae. London: Royal Botanic Gardens, Kew; 2007. http://apps.kew. org/wcsp/.

35. USDA-ARS. Germplasm Resources Information Network (GRIN). Online Database Beltsville, Maryland, USA, National Germplasm Resources Laboratory. 2014; https://npgsweb.ars-grin.gov/gringlobal/taxon/ taxonomysearch.aspx.

36. Holm LG, Plucknett DL, Pancho JV, Herberger JP. The world's worst weeds: Their distribution and biology; 1977. p. XF2006176107.

37. Defelice MS. Yellow Nutsedge Cyperus esculentus L.-Snack Food of the Gods. Weed Technol. 2002;16:901-7.

38. Dodet M, Petit RJ, Gasquez J. Local spread of the invasive Cyperus esculentus (Cyperaceae) inferred using molecular genetic markers. Weed Res. 2008; 48(1):19-27.

39. Arafat S, Gaafar A, Basuny A, Nassef S. Chufa Tubers (Cyperus esculentus L.): as a new source of food. World Appl Sci J. 2009:7(2):151-6.

40. Bado S, Bazongo P, Son G, Kyaw MT, Forster BP, Nielen S, Lykke AM, Ouédraogo A, Bassolé IHN. Physicochemical characteristics and composition of three Morphotypes of Cyperus esculentus tubers and tuber oils. J Anal Methods Chem. 2015;2015:1-8.

41. Belewu M, Belewu K. Comparative physico chemical evaluation of Tiger-nut, soybean and coconut milk sources. Int J Agric Biol. 2007;9(5):788-90.

42. Sakuma Y, Liu Q, Dubouzet JG, Abe H, Shinozaki K, Yamaguchi-Shinozaki K. DNA-binding specificity of the ERF/AP2 domain of Arabidopsis DREBs, transcription factors involved in dehydration- and cold-inducible gene expression. Biochem Biophys Res Commun. 2002;290(3):998-1009.

43. Nakano T, Suzuki K, Fujimura T, Shinshi H. Genome-wide analysis of the ERF gene family in Arabidopsis and rice. Plant Physiol. 2006;140(2):411-32.

44. Swaminathan K, Peterson K, Jack T. The plant B3 superfamily. Trends Plant Sci. 2008;13(12):647-55.

45. Pei ZM, Ghassemian M, Kwak CM, McCourt P, Schroeder Jl. Role of farnesyltransferase in ABA regulation of guard cell anion channels and plant water loss. Science. 1998;282(5387):287-90.

46. Vijayalakshmi T, Varalaxmi Y, Singh J. Sushil Yadav, Maddi Vanaja, Jyothilakshmi N, Maheswari Mandapaka. Physiological and biological basis of water- deficit stress tolerance in pearl millet hybrid and parents. Am J Plant Sci. 2012;3:1730-40.

47. Manavalan LP, Guttikonda SK, Tran LS, Nguyen HT. Physiological and molecular approaches to improve drought resistance in soybean. Plant Cell Physiol. 2009;50(7):1260-76.

48. Li Y, Zhang J, Zhang J, Hao L, Hua J, Duan L, Zhang M, Li Z. Expression of an Arabidopsis molybdenum cofactor sulphurase gene in soybean enhances drought tolerance and increases yield under field conditions. Plant Biotechnol J. 2013;11(6):747-58.

49. Yu L, Chen X, Wang Z, Wang S, Wang Y, Zhu Q, Li S, Xiang C. Arabidopsis enhanced drought tolerance1/HOMEODOMAIN GLABROUS11 confers drought tolerance in transgenic rice without yield penalty. Plant Physiol. 2013;162(3):1378-91.

50. Gindel I. Stomatal number and size as related to soil moisture in tree xerophytes in Israel. Ecology. 1969;50:263-7.

51. Franks PJ, Doheny-Adams TW, Britton-Harper ZJ, Gray JE. Increasing wateruse efficiency directly through genetic manipulation of stomatal density. New Phyto1. 2015;207:188-95.

52. Doheny-Adams T, Hunt L, Franks PJ, Beerling DJ, Gray JE. Genetic manipulation of stomatal density influences stomatal size, plant growth and 
tolerance to restricted water supply across a growth $\mathrm{CO} 2$ gradient. Philos Trans R Soc B: Biol Sci. 2012:367:547-55.

53. Niederl S, Kirsch T, Riederer M, Schreiber L. Co-permeability of 3H-labeled water and 14C-labeled organic acids across isolated plant Cuticles: investigating Cuticular paths of diffusion and predicting Cuticular transpiration. Plant Physiol. 1998;116:117-23.

54. Yuan GF, Jia C, Li Z, Sun B, Zhang LP, Liu N, Wang QM. Effect of brassinosteroids on drought resistance and abscisic acid concentration in tomato under water stress. Sci Hortic. 2010;126(2):103-8.

55. Nawrath C. Unraveling the complex network of cuticular structure and function. Curr Opin Plant Biol. 2006;9(3):281-7.

56. Patwari P, Salewski V, Gutbrod K, Kreszies T, Dresen-Scholz B, Peisker H, Steiner U, Meyer AJ, Schreiber L, Dörmann P. Surface wax esters contribute to drought tolerance in Arabidopsis. Plant J. 2019;98(4):727-44.

57. Liu D, Wu L, Naeem MS, Liu H, Deng X, Xu L, Zhang F, Zhou W. 5Aminolevulinic acid enhances photosynthetic gas exchange, chlorophyll fluorescence and antioxidant system in oilseed rape under drought stress. Acta Physiol Plant. 2013;35(9):2747-59.

58. Li L, Li J, Shen M, Zhang C, Dong Y. Cold plasma treatment enhances oilseed rape seed germination under drought stress. Sci Rep. 2015;5:13033.

59. Ashraf M, Foolad MR. Roles of glycine betaine and proline in improving plant abiotic stress resistance. Environ Exp Bot. 2007;59(2):206-16.

60. Talbi S, Romero-Puertas MC, Hernández A, Terrón L, Ferchichi A, Sandalio LM. Drought tolerance in a Saharian plant Oudneya africana: role of antioxidant defences. Environ Exp Bot. 2015;111:114-26.

61. Liu H, Zhang YH, Yin H, Wang WX, Zhao XM, Du YG. Alginate oligosaccharides enhanced Triticum aestivum L. tolerance to drought stress. Plant Physiol Biochem. 2013;62:33-40.

62. Wan YY, Chen SY, Huang YW, Li X, Zhang Y, Wang XJ, Bai JG. Caffeic acid pretreatment enhances dehydration tolerance in cucumber seedlings by increasing antioxidant enzyme activity and proline and soluble sugar contents. Sci Hortic. 2014;173:54-64.

63. Cheng C, Hu J, Zhi Y, Su JJ, Zhang XK, Huang BQ. Cloning and characterization of ADP-glucose pyrophosphorylase small subunit gene in Cyperus esculentus (yellow nutsedge). Genet Mol Res. 2015;14(4):18302-14.

64. Altschul SF, Lipman DJ. Protein database searches for multiple alignments. Proc Natl Acad Sci U S A. 1990;87:5509-13.

65. Wang CG, Zhang JH, Xie Y, Liu YQ, Huang BQ. Cloning and hpRNAi vector construction of Brassica napus pyrophosphate-dependent phosphofructokinase (PFK). Mol Plant Breed. 2006;02:56-61.

66. Bent AF, Clough SJ. Agrobacterium Germ-Line Transformation: Transformation of Arabidopsis without Tissue Culture. In: Plant Molecular Biology Manual. Edited by Gelvin SB, Schilperoort RA. Dordrecht: Springer Netherlands; 1998. p. 17-30.

67. Wei T, Deng K, Gao Y, LiuY YM, Zhang L, Zheng X, Wang C, Song W, Chen C, Zhang Y. Arabidopsis DREB1B in transgenic Salvia miltiorrhiza increased tolerance to drought stress without stunting growth. Plant Physiol Biochem. 2016;104:17-28

68. Dhindsa R, Matowe W. Drought tolerance in two mosses: correlated with enzymatic Defence against lipid peroxidation. J Exp Bot. 1981;32:79-91.

69. Troll W, Lindsley J. A photometric method for the determination of proline. J Biol Chem. 1955;215(2):655-60.

70. Flood AE, Priestley CA. Two improved methods for the determination of soluble carbohydrates. J Sci Food Agric. 1973;24(8):945-55.

\section{Publisher's Note}

Springer Nature remains neutral with regard to jurisdictional claims in published maps and institutional affiliations.

Ready to submit your research? Choose BMC and benefit from:

- fast, convenient online submission

- thorough peer review by experienced researchers in your field

- rapid publication on acceptance

- support for research data, including large and complex data types

- gold Open Access which fosters wider collaboration and increased citations

- maximum visibility for your research: over $100 \mathrm{M}$ website views per year

At BMC, research is always in progress.

Learn more biomedcentral.com/submissions 